\title{
Analisis Faktor-Faktor (7P) Yang Mempengaruhi Minat Lulusan SMU/ Sederajat Melanjutkan Studinya di Universitas Widyatama
}

\author{
Achirsyah Bahar \\ Program Magister Manajemen Universitas Widyatama Bandung \\ Email:
}

\begin{abstract}
ABSTRAK
Marketing menjadi salah satu andalan Univesiitas Wiidyatama dalam menarik minat lulusan SMU/Sederajat untuk mendaftarkan diri sebagai calon mahasiswanya. Salah satu cara yang dilakukan dalam menarik minat siswa lulusan SMU/Sederajat ialah dengan melakukan penelitian yang melibatkan berbagai aspek yang menjadi pilihan siswa lulusan SMU/Sederajat. Penelitian yang dilakukan ialah dengan menggunakan metode bauran pemasaran (7P) yang terdiri dari Product (produk), Price (harga), Promotion (promosi), Place (tempat), People (orang), Process (proses) dan Phisical Evidence (sarana phisik). Penelitian ini dilakukan terhadap 160 responden yang terdiri atas calon mahasiswa baru (pendaftar) dan mahasiswa widyatama dari berbagai angkatan.
\end{abstract}

Hasil penelitian menunjukkan bahwa faktor-faktor yang mempengaruhi minat lulusan SMU/Sederajat dalam melanjutkan studinya di Universitas Widyatama adalah:

1. Variabel Product, Price, Promotion, Place, Person, Process dan Phisical Evidence menunjukan nilai yang signifikan terhadap pilihan responden, yaitu sebagai berikut :

a. Untuk variabel product (produk) 61\% menyatakan sangat setuju, 28,4\% menyatakan setuju dan 10,5\% Netral.

b. Untuk variabel price (harga) 51,25\% menyatakan sangat setuju,30,83\% setuju, 14,17\% menyatakan netral dan 3,75\% tidak setuju

c. Untuk variabel promotion (promosi) 35,42\% menyatakan sangat setuju, 38,75\% menyatakan setuju, sisanya netral dan tidak setuju

d. Untuk variabel place (tempat) 39,69\% menyatakan sangat setuju, 29,06\% menyatakan setuju dan sisanya netral dan tidak setuju.

e. Untuk Variabel person (orang) 52,92\% menyatakan sangat setuju, 33,33\% menyatakan setuju, sisanya netral dan tidak setuju.

f. Untuk Variabel process (proses) 48,25\% menyatakan sangat setuju, 39\% menyatakan setuju dan sisanya netral dan tidak setuju.

g. Untuk Variabel phisical evidence (fasilitas fisik) 41,67\% menyatakan sangat setuju, 43,33\% menyatakan setuju dan sisanya netral dan tidak setuju.

2. Pengaruh faktor-faktor bauran pemasaran model $7 P$ terhadap minat lulusan SMU / Sederajat dalam melanjutkan studinya di Universitas Widyatama menunjukkan bahwa berdasarkan uji secara overall hasil pengujiannya signifikan. Tapi berdasarkan uji individual dengan resiko kekeliruan 5\%, hasil pengujiaannya menunjukkan bahwa Product (produk), Price (harga), Promotion (promosi) dan Place (tempat) memberikan pengaruh yang signifikan, sedangkan faktor Person (orang), Process (proses) dan Phisycal Evidence (fasilitas fisik) tidak memberikan pengaruh yang signifikan.

Kata Kunci: Minat, Mahasiswa, Metode (7P), Pemasaran 


\section{PENDAHULUAN}

Persaingan antar Perguruan Tinggi dalam menarik siswa lulusan SMU / Sederajat sat ini terasa semakin ketat. Menurunnya jumlah lulusan SMU / Sederajat yang akan melanjutkan studinya di Perguruan tinggi menjadi tantangan bagi setiap perguruan tinggi untuk memberikan pelayanan yang terbaik, disamping status sekolah yang telah memperoleh akreditasi dari Kementrian Riset, Teknologi dan Perdidikan Tinggi.

Universitas Widyatama merupakan salah satu universitas terkemuka di Bandung yang telah terakreditasi A untuk jurusan Manajemen, Akuntansi dan D3 bahasa Jepang. Sedangkan jurusan lainnya yaitu jurusan S1 teknik yang terdiri dari jurusan Teknik Industri, Teknik Informatika dan S1 Sistem Informasi, S1 Bahasa Inggris, S1 Bahasa Jepang dan S1 Desain Komunikasi Visual (DKV) sudah terakreditasi B. Untuk mempertahankan jumlah peminatnya, salah satu cara yang dilakukan ialah dengan membuat penelitian yang berjudul "Analisa Faktor-Faktor (7P) Yang Mempengaruhi Minat Lulusan SMU / Sederajat Dalam Melanjutkan Studinya di Universitas Widyatama”.. Penelitian diharapkan berguna bagi Universitas Widyatama, antara lain:

1. Dalam menganalisis faktor-faktor apa saja yang dominan bagi lulusan SMU / Sederajat memilih Universitas Widyatama sebagai pilihan utamanya.

2. Seberapa besar faktor-faktor tersebut dapat mempengaruhi siswa lulusan SMU / Sederajat melanjutkan studinya di Universitas Widyatama.

\section{METODOLOGI}

\subsection{Pengertian Minat :}

Mengutip dari pernyataan JP. Chaplin [1] yaitu :

1.Minat adalah sikap murni yang mengikut sertakan perhatian pribadi dalam pemilihan terhadap suatu objek.

3. Minat adalah perasaan khusus, kegemaran atau objek yang penting bagi individu.

4.Minat adalah suatu dorongan yang menuntun kelakuan individu

Philip Kotler [2] menyatakan bahwa minat dipengaruhi oleh 5 faktor psikologis utama, yaitu persepsi, motivasi, pengetahuan, kepercayaan dan pendirian. Maka dapat dismpulkan bahwa minat adalah dorongan yang timbul dalam diri seseorang untuk melakukan suatu objek yang dianggap penting bagi individu itu sendiri, tetapi dalam pernyataannya di pengaruhi oleh faktor-faktor persepsi, motivasi, pengetahuan, kepercayaan dan pendirian.

\subsection{Pemasaran}

Pendapat beberapa ahli mengenai pemasaran yang dikutip oleh Djaslim Saladin [3] adalah sebagai berikut :

a. Pemasaran adalah suatu sistem total dari kegiatan bisnis yang dirancang untuk mendistribusikan barang yang dapat memuaskan keinginan dan mencapai sasaran serta lujuan Organisasi [4]

b. Pemasaran adalah suatu proses yang berfokus pada sumber daya manusia dan bertujuan untuk memanfaatkan peluang-peluang pasar secara global [5].

c. Pemasaran adalah proses sosial yang didalamnya individu atau kelompok memperoleh apa yang mereka butuhkan dan inginkan dengan menciptakan, menawarkan dan mempertukarkan produk dan jasa dengan orang lain [6].

d. Pemasaran adalah suatu proses dan manajerial dari individu dan kelompok untuk memenuhi kebutuhan dan keinginannya melalui penciptaan, penawaran dan pertukaran produk yang lain [3].

Dari keterangan para ahli pemasaran dapat disimpulkan bahwa pemasaran ialah merupakan suatu cara dalam memasarkan suatu produk yang kita jual, dimana produk tersebut disamping dapat terjual juga harus dapat memuaskan konsumen dengan memanfaatkan pasar global, sehingga produk yang ditawarkan selain dapat memenuhi target yang diinginkan juga dapat memperoleh customer-customer baru untuk penjualan produk selanjutnya. 


\subsection{Bauran Pemasaran}

Bauran pemasaran merupakan salah satu kiat pemasaran yang digunakan perusahaan untuk mencapai sasaran pemasarannya. Philip Kotler [6] mengatakan bahwa Bauran Pemasaran terdiri dari 4 elemen (Produk, Price, Place \& Promotion) dapat dilihat dalam gambar seperti dibawah ini :

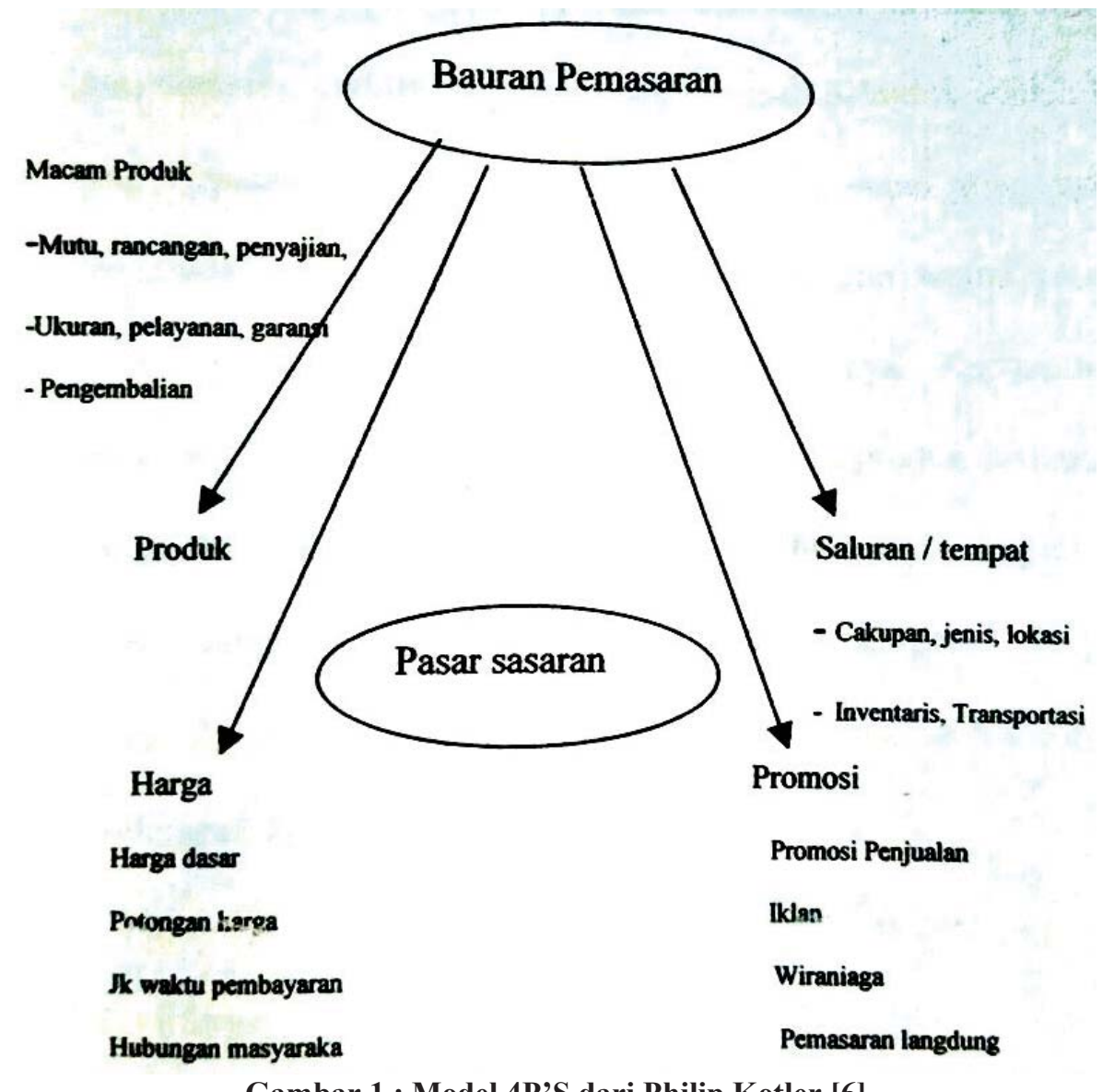

Gambar 1 : Model 4P'S dari Philip Kotler [6]

Model 4P'S yang mulanya merupakan bauran pemasaran barang diperluas menjadi 7 P'S untuk digunakan dalam pemasaran jasa [7]. Keterangan Zeithmal \& Bitner yang dikutip oleh Yazid [7] menambahkan 3 faktor lagi yaitu Person (orang), dimana orang terlibat dalam menjalankan aktivitas yang dilakukan perusahaan, Process (proses) yaitu upaya yang dilakukan perusahaan untuk memuaskan konsumennya, serta Phisical Evidence (fasilitas fisik) dimana sarana fisik yang ada dapat mempengaruhi kepentingan konsumen terhadap jasa yang ditawarkan. 


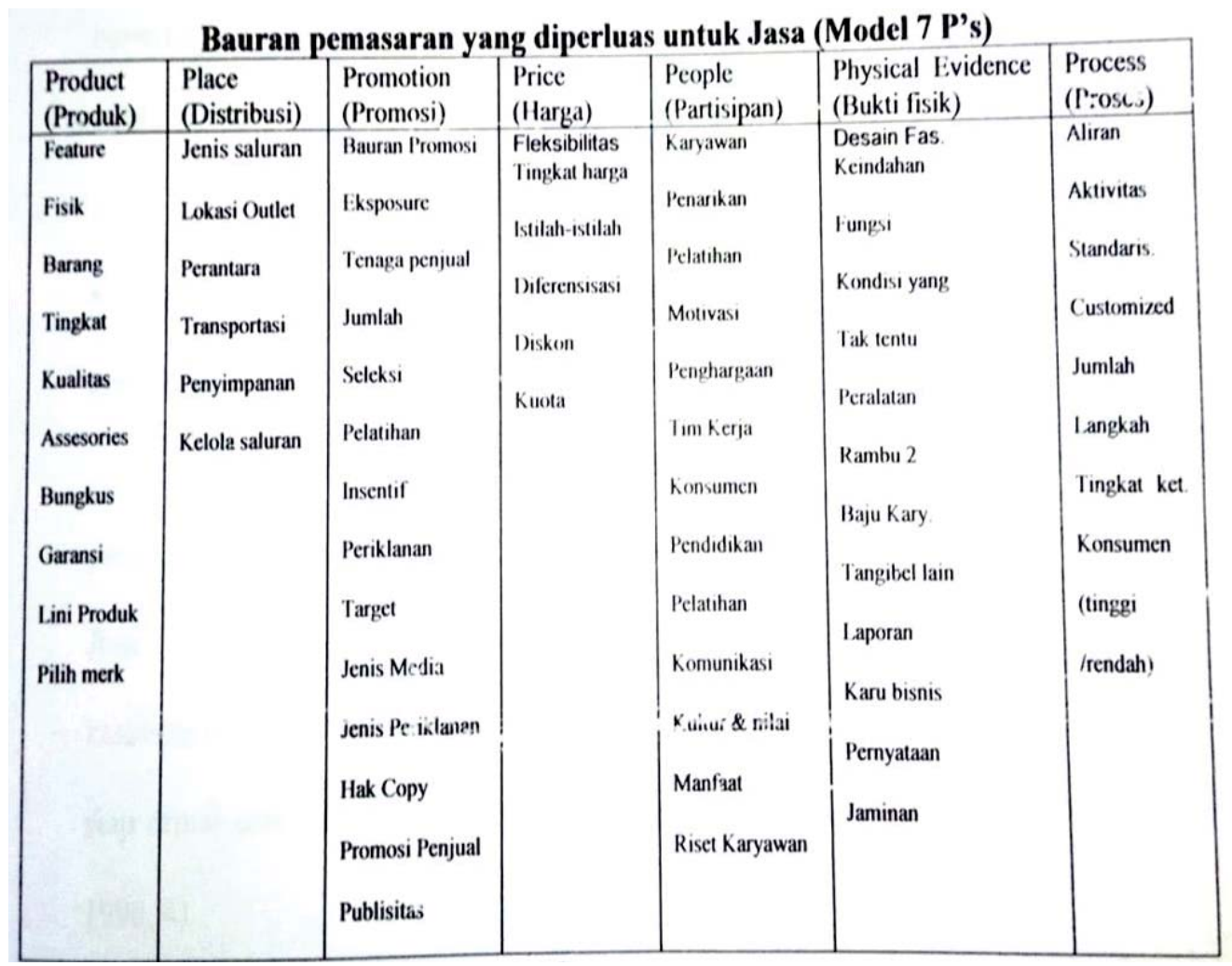

Gambar 2 : Model 7P'S [8]

\subsection{Perilaku Konsumen}

Konsumen merupakan subjek yang sangat penting dalam penelitian ini, karena keputusan yang diambil oleh konsumen telah melalui tahapan pertimbangan dari berbagai aspek. Keputusan yang diambil konsumen ialah nilai inti, yaitu sistem kepercayaan yang melandasi sikap dan perilaku konsumen.Nilai inti itu jauh lebih dalam dari pada perilaku atau sikap, dan pada dasarnya menentukan pilihan dan keinginan oorang dalam jangka panjang.

Pemasar yang menargetkan konsumen berdasarkan pada keyakinan nilai mereka dengan menarik bagi inner-selves orang sendiri, adalah mungkin untuk mempengaruhi outer-selves mereka.atau perilaku pembelian mereka. Hal ini dapat dilihat dari pendapat Kotler \& Keller [2] seperti dibawah ini.

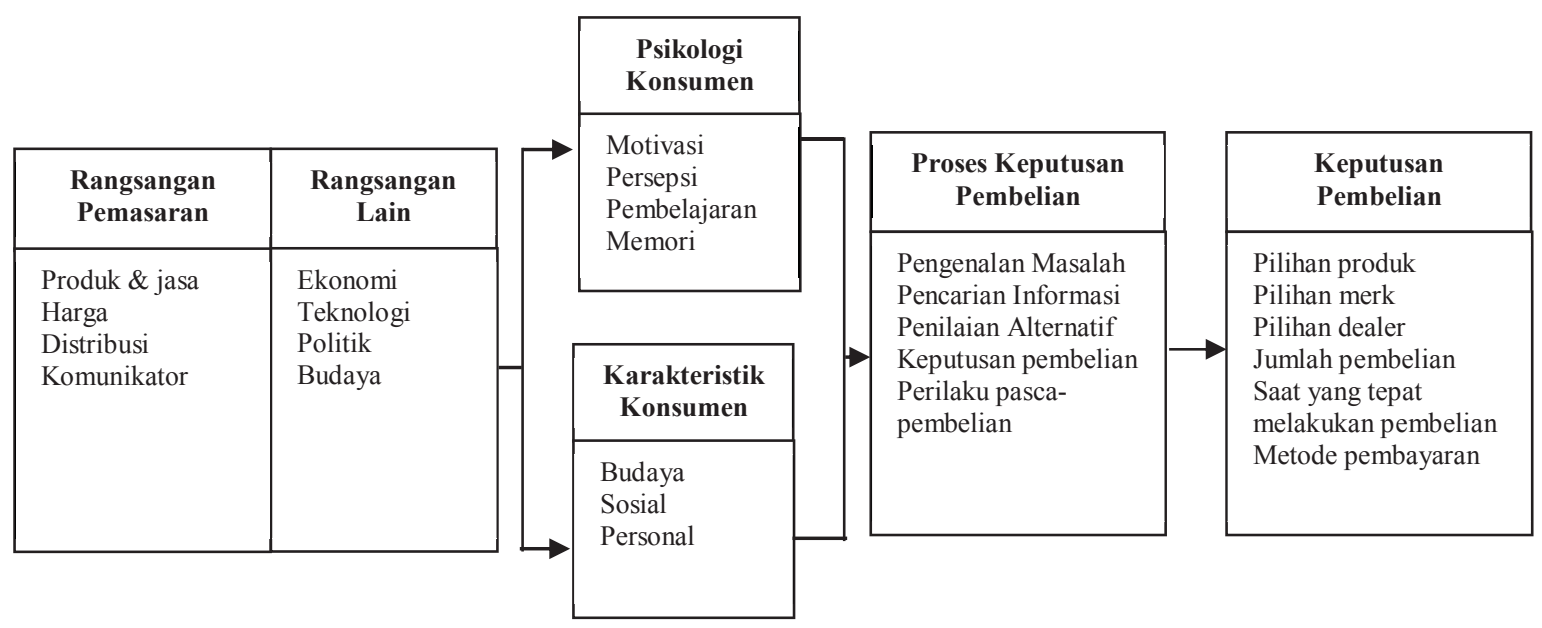

Gambar 3 Model Perilaku Konsumen [2] 


\subsection{Teknik Pengolahan Data}

Pengolahan data dilakukan dengan menggunakan 2 Variabel, yaitu:

1. Menggunakan variabel Independen (X)

Bauran Pemasaran yang terdiri dari 7P kita bagi menjadi 7 Variabel yang terdiri dari X1 (Product), X2 (Price), X3 (Promotion), X4 (Place), X5 (People), X6 (People) dan X7 (Phisycal Evidence). Setiap satuan elementer dari populasi mempunyai kesempatan yang sama untuk dipilih sebagai sampel.

2. Menggunakan Variabel Dependen (Y)

Adalah suatu variabel tidak bebas yang keberadaanya ditentukan oleh variabel Independen. Dalam penelitian ini keputusan konsumen untuk mendaftar di identifikasikan sebagai variabel Dependen (Y), yaitu suatu variabel tidak bebas yang keberadaanya ditentukan oleh variabel Independen.

3. Metode Penarikan Sampel

Digunakan metode pengambilan sampel acak sederhana (sample random sampling), yaitu sebuah sampel yang diambil sedemikian rupa, sehingga setiap satuan elementer dari populasi mempunyai kesempatan yang sama untuk dipilih sebagai sampel.

Persamaan yang digunakan ialah :

$\mathrm{n}=((\mathrm{Z} \alpha / 2) / 2 \mathrm{BE}) 2$

Dengan $\alpha=95 \%$

$\mathrm{d}=10 \%$

Populasi sebesar 3000 (jumlah mahasiswa yg mendaftar)

Diperoleh nilai $\mathrm{n}=96,04$

Artinya jumlah sampel minimal yang harus diteliti ialah 96 responden. Sampel yang berhasil diteliti adalah 160 orang dengan derajat kepercayaan $95 \%$ dan toleransi error $10 \%$. Maka jumlah responden sebagai sampel dalam penelitian ini telah memenuhi persyaratan.

\subsection{Metode Pengumpulan Data}

Pengumpulan data dilakukan dengan menggunakan 2 cara, yaitu :

1. Dengan melakukan penelitian lapangan, dimana data diperoleh melalui survey langsung ketempat penelitian. Mengadakan observasi langsung, wawancara dengan pihak manajemen, mengolah data, dan menyebarkan kuesioner ke sumber penelitiannya langsung. Kuesioner yang digunakan berupa multiple choice question dan bersifat tertutup dengan skala sikap berpedoman pada skala Likert. Responden diminta tanggapan atas pertanyaan-pertanyaan yang diberikan apakah setuju / tidak setuju ataukah memiliki kepentingan yang tinggi / rendah terhadap pertanyaan yang diajukan.

2. Dengan melakukan penelitian kepustakaan dengan mempelajari berbagai teori yang berkaitan dengan penelitian ini dan memperoleh informasi dengan mempelajari berbagai literatur yang menjadi referensi acuan penelitian ini.

3. Teknik Pengolahan Data

Data yang diperoleh dari kuesioner diolah dengan pendekatan kualitatif dan kuantitatif. 


\subsection{Metode Analisis}

Ada 2 metode yang digunakan dalam menganalisi data yang diperoleh, yaitu :

1. Metode Konversi Data, dimana data dikumpulkan dalam tiga kelompok yaitu persiapan, tabulasi dan penerapan data dengan pendekatan penelitian. Metode yang digunakan ialah Likert Summated Rating yang berguna untuk mengkategorikan sikap responden [9]. Disamping itu digunakan juga Method of Successive Interval untuk memberikan keterang mengenai kualitas pelayanan dan keputusan konsumen dalam melakukan pembelian.

2. Analisis Jalur (Path Analysis)

Analisis ini digunakan untuk menentukan berapa besar pengaruh suatu variabel terhadap variabel lainnya, baik langsung maupun tidak langsung. Besarnya pengaruh dari suatu variabel penyebab (Independen) terhadap variabel akibat (dependen).

\section{HASIL DAN PEMBAHASAN}

Tabel 1 Tahun angkatan lulusan SMU / Sederajat yang mendaftar

\begin{tabular}{ccccc}
\hline Tahun & Frequency & Percent & Valid Percent & Cum (Percent) \\
\hline 2015 & 78 & 48,75 & 48,75 & 48,75 \\
\hline $2013-2014$ & 44 & 30 & 30 & 78,75 \\
\hline $2011-2012$ & 26 & 16,25 & 16,25 & 95 \\
\hline Sebl. 2011 & 8 & 5 & 5 & 100 \\
\hline Total & $\mathbf{1 6 0}$ & $\mathbf{1 0 0}$ & $\mathbf{1 0 0}$ & \\
\hline Sumber : penelitian lapangan 2015 & & &
\end{tabular}

Tabel 2 Daerah asal siswa lulusan SMU / Sederajat yang mendaftar

\begin{tabular}{ccccc}
\hline Daerah asal & Frequency & Percent & Valid Percent & Cum (Percent) \\
\hline Bandung-Cimahi & 82 & 56,25 & 56,25 & 51,25 \\
\hline Jakarta \&Jabar & 44 & 27,5 & 27,5 & 78,75 \\
\hline Jateng \&Jatim & 12 & 7,5 & 7,5 & 86,25 \\
\hline Luar Jawa & 22 & 13,75 & 13,75 & 100 \\
\hline Total & $\mathbf{1 6 0}$ & $\mathbf{1 0 0}$ & $\mathbf{1 0 0}$ & \\
\hline
\end{tabular}

Sumber : penelitian lapangan 2015

Tabel 3 Jurusan yang diminati siswa lulusan SMU / Sederajat yang mendaftar

\begin{tabular}{ccccc}
\hline Jurusan & Frequency & $\begin{array}{c}\text { Percent } \\
(\mathbf{\%})\end{array}$ & $\begin{array}{c}\text { Valid Percent } \\
(\mathbf{\%})\end{array}$ & $\begin{array}{c}\text { Cumulative (Percent) } \\
(\mathbf{\%})\end{array}$ \\
\hline Ekonomi Akutansi & 46 & 28,75 & 28,75 & 28,75 \\
Ekonomi Manajemen & 60 & 37,5 & 37,5 & 66,25 \\
\hline Teknik Industri & 16 & 10 & 10 & 76,25 \\
Teknik Informatika & 8 & 5 & 5 & 81,25 \\
Sistem Informasi & 6 & 3,75 & 3,75 & 85 \\
\hline Bahasa Ingrris & 8 & 5 & 5 & 90 \\
Bahasa Jepang & 6 & 3,75 & 3,75 & 93,75 \\
\hline Desain Grafis & 4 & 2,5 & 2,5 & 96,25 \\
Desain Multimedia & 4 & 2,5 & 2,5 & 98,75 \\
Desain Periklanan & 2 & 1,25 & 1,25 & 100 \\
\hline Total & $\mathbf{1 6 0}$ & $\mathbf{1 0 0}$ & $\mathbf{1 0 0}$ & \\
\hline
\end{tabular}

Sumber : penelitian lapangan 2015 
Tabel 4. Hasil pengolahan data kuesioner mengenai pengaruh minat terhadap Siswa lulusan SMU / Sederajat

\begin{tabular}{|c|c|c|c|c|c|c|c|c|c|c|}
\hline \multirow{2}{*}{ Uraian } & \multicolumn{2}{|c|}{ 1.Motivasi } & \multicolumn{2}{|c|}{$\begin{array}{l}\text { 2.Persepsi } \\
\text { Individual }\end{array}$} & \multicolumn{2}{|c|}{ 3.Pengetahuan } & \multicolumn{2}{|c|}{$\begin{array}{l}\text { 4.Kepribadian/ } \\
\text { Gaya hidup }\end{array}$} & \multicolumn{2}{|c|}{$\begin{array}{c}\text { 5.Kepercayaan/ } \\
\text { Keyakinan }\end{array}$} \\
\hline & Freq & $\%$ & Freq & $\%$ & Freq & $\%$ & Freq & $\%$ & Freq & $\%$ \\
\hline Sangat Penting & 90 & 56,2 & 78 & 48,8 & 46 & 28,8 & 36 & 22,5 & 118 & 73,8 \\
\hline Penting & 46 & 28,8 & 44 & 27,5 & 66 & 41,2 & 50 & 31,25 & 26 & 16,3 \\
\hline Normal & 24 & 15 & 22 & 13,7 & 48 & 30 & 54 & 33,75 & 16 & 8 \\
\hline Tidak Penting & 0 & 0 & 16 & 10 & 0 & 0 & 16 & 10 & 0 & 0 \\
\hline Sgt tdk penting & 0 & 0 & 0 & 0 & 0 & 0 & 4 & 2,5 & 0 & 0 \\
\hline & 160 & 100 & 160 & 100 & 160 & 100 & 160 & 100 & 160 & 100 \\
\hline
\end{tabular}

Hasil pengolahan data kuesioner terhadap siswa lulusan SMU/Sederajat Dengan menggunakan sistem bauran pemasaran model $7 \mathrm{P}$, dibawah ini akan dijelaskan penggunaan kode dan penjelasan dari setiap kode yang digunakan, yaitu sebagai berikut :

\begin{tabular}{cccc}
\hline Nomer & Kode & Penjelasan Aktivitas & Nama Aktivitas \\
\hline 1 & X1 & Produk Universitas Widyatama & Product (produk) \\
\hline 2 & X2 & Biaya Perkuliahan di Unversitas Widyatama & Price (harga) \\
\hline 3 & X3 & $\begin{array}{c}\text { Promosi yang dilakukan oleh Universitas } \\
\text { Widyatama }\end{array}$ & $\begin{array}{c}\text { Promotion } \\
\text { (promosi) }\end{array}$ \\
\hline 4 & X4 & Tempat Lokasi Universitas Widyatama & Place (tempat) \\
\hline 5 & X5 & $\begin{array}{c}\text { Orang yang berhubungan dengan kegiatan } \\
\text { kemahasiswaan di Universitas Widyatama }\end{array}$ & People (orang) \\
\hline 6 & X6 & $\begin{array}{c}\text { Proses kegiatan kemahasiswaan di Universitas } \\
\text { Widyatama }\end{array}$ & Process (proses) \\
\hline 7 & X7 & Fasilitas fisik yang disediakan oleh Universitas & $\begin{array}{c}\text { Phisycal Evidence } \\
\text { (fasilitas fisik) }\end{array}$ \\
\hline
\end{tabular}

Hasil pengolahan data kuesioner terhadap siswa lulusan SMU / Sederajat dengan menggunakan sistem Bauran Pemasaran model P7 adalah sebagai berikut :

1. Produk Universitas Widyatama (Product)

\begin{tabular}{|c|c|c|c|c|c|c|c|c|c|c|}
\hline \multirow[t]{2}{*}{$\begin{array}{l}\text { Tanggapan } \\
\text { Responden }\end{array}$} & \multicolumn{2}{|c|}{$\begin{array}{c}\text { 1.Nama besar } \\
\text { Universitas } \\
\text { Widyatama }\end{array}$} & \multicolumn{2}{|c|}{$\begin{array}{c}\text { 2.Kualitas } \\
\text { Akreditas } \\
\text { Uinversitas } \\
\text { Widyatama }\end{array}$} & \multicolumn{2}{|c|}{$\begin{array}{c}\text { 3.Tersedia } \\
\text { jurusan yang } \\
\text { sesuai minat }\end{array}$} & \multicolumn{2}{|c|}{$\begin{array}{c}\text { 4.Jadwal } \\
\text { Kegiatan } \\
\text { Akademik }\end{array}$} & \multicolumn{2}{|c|}{$\begin{array}{c}\text { 5.Fasilitas } \\
\text { Perpustakaan \& } \\
\text { Laboratorium }\end{array}$} \\
\hline & Freq & $\%$ & Freq & $\%$ & Freq & $\%$ & Freq & $\%$ & Freq & $\%$ \\
\hline $\begin{array}{l}\text { Sangat } \\
\text { Penting }\end{array}$ & 100 & 62,5 & 100 & 62,5 & 96 & 60 & 49 & 61,25 & 94 & 58,75 \\
\hline Penting & 44 & 27,5 & 44 & 27,5 & 46 & 28,75 & 24 & 30 & 46 & 28,75 \\
\hline Normal & 16 & 10 & 16 & 10 & 18 & 11,25 & 7 & 8,75 & 20 & 12,5 \\
\hline Tidak Penting & 0 & 0 & 0 & 0 & 0 & 0 & 0 & 0 & 0 & 0 \\
\hline $\begin{array}{l}\text { Sgt tdk } \\
\text { penting }\end{array}$ & 0 & 0 & 0 & 0 & 0 & 0 & 0 & 0 & 0 & 0 \\
\hline & 160 & 100 & 160 & 100 & 160 & 100 & 160 & 100 & 160 & 100 \\
\hline
\end{tabular}

Dari data produk Universitas Widyatama, diketahui bahwa :

a. Nama besar Universitas Widyatama \& kualitas akreditasinya menempati urutan pertama pilihan mahasiswa dengan $62,5 \%$ menyatakan sangat penting, $27,5 \%$ menyatakan penting dan sisanya Normal.

b. Jadwal kegiatan akademik, jurusan yang sesuai minat dan fasilitas perpustakaan \&laboratorium merupakan pilihan berikutnya. 
2. Biaya perkuliahan di Universitas Widyatama (Price)

\begin{tabular}{|c|c|c|c|c|c|c|}
\hline \multirow[t]{2}{*}{$\begin{array}{l}\text { Tanggapan } \\
\text { Responden }\end{array}$} & \multicolumn{2}{|c|}{$\begin{array}{l}\text { 1. Biaya Perkuliahan } \\
\text { yg terjangkau oleh } \\
\text { orang tua siswa }\end{array}$} & \multicolumn{2}{|c|}{$\begin{array}{l}\text { 2. Biaya Perkuliahan yang } \\
\text { sesuai dengan fasilitas } \\
\text { yang diberikan oleh } \\
\text { Universitas Widyatama }\end{array}$} & \multicolumn{2}{|c|}{$\begin{array}{l}\text { 3. Adanya program } \\
\text { beasiswa untuk siswa } \\
\text { berprestasi yg } \\
\text { kurang mampu }\end{array}$} \\
\hline & Freq & $\%$ & Freq & $\%$ & Freq & $\%$ \\
\hline Sangat Penting & 88 & 55 & 80 & 50 & 78 & 48,75 \\
\hline Penting & 52 & 32,5 & 52 & 32,5 & 44 & 27,5 \\
\hline Normal & 20 & 12,5 & 26 & 16,25 & 22 & 13,75 \\
\hline Tidak Penting & 0 & 0 & 2 & 1,25 & 16 & 10 \\
\hline Sgt tdk penting & 0 & 0 & 0 & 0 & 0 & 0 \\
\hline & 160 & 100 & 160 & 100 & 160 & 100 \\
\hline
\end{tabular}

Untuk biaya perkuliahan, hasil penelitian menunjukkan bahwa :

a. Biaya perkuliahan yang terjangkau oleh orang tua siswa menjadi pilihan utama mahasiswa dengan jumlah 55\% pemilih dari 160 responden

b. Pilihan kedua dan ketiga adalah biaya perkuliahan yang sesuai dengan fasilitas yang diberikan oleh Universitas Widyatama sebesar $50 \%$ pemilih dan program beasiswa untuk mahasiswa berprestasi yang kurang mampu sebesar $48,75 \%$ pemilih.

3. Promosi (Promotion)

\begin{tabular}{|c|c|c|c|c|c|c|}
\hline \multirow[t]{2}{*}{$\begin{array}{l}\text { Tanggapan } \\
\text { Responden }\end{array}$} & \multicolumn{2}{|c|}{$\begin{array}{l}\text { 1. Adanya promosi yg } \\
\text { menarik melalui } \\
\text { brosur-brosur, } \\
\text { poster-poster, surat } \\
\text { kabar, internet, dll }\end{array}$} & \multicolumn{2}{|c|}{$\begin{array}{l}\text { 2. Adanya pembicaraan } \\
\text { dari mulut kemulut } \\
\text { yang dilakukan oleh } \\
\text { para siswa lulusan } \\
\text { SMU/ Sederajat }\end{array}$} & \multicolumn{2}{|c|}{$\begin{array}{l}\text { 3. Adanya seminar2 yg } \\
\text { dilakukan oleh } \\
\text { Universitas Widyatama } \\
\text { dalam rangka } \\
\text { memperkenalkan } \\
\text { program } 2 \text { barunya }\end{array}$} \\
\hline & Freq & $\%$ & Freq & $\%$ & Freq & $\%$ \\
\hline Sangat Penting & 44 & 27,5 & 80 & 50 & 46 & 28,75 \\
\hline Penting & 70 & 43,75 & 50 & 31,25 & 66 & 41,25 \\
\hline Normal & 30 & 18,75 & 30 & 18,75 & 48 & 30,0 \\
\hline Tidak Penting & 14 & 8,75 & 0 & 0 & 0 & 0 \\
\hline Sgt tdk penting & 2 & 1,25 & 0 & 0 & 0 & 0 \\
\hline & 160 & 100 & 160 & 100 & 160 & 100 \\
\hline
\end{tabular}

Untuk Promosi, hasil penelitian menunjukkan bahwa :

a. Adanya pembicaraan dari mulut kemulut merupakan pilihan pertama dengan jumlah $50 \%$ pemilih.

b. Seminar-seminar yang dilakukan oleh Universitas Widyatama dan promosi yang menarik melalui brosur2, poster2, surat kabar \& internet merupakan pilihan kedua dan ketiga

4. Tempat (Place)

\begin{tabular}{|c|c|c|c|c|c|c|c|c|}
\hline \multirow[t]{2}{*}{$\begin{array}{l}\text { Tanggapan } \\
\text { Responden }\end{array}$} & \multicolumn{2}{|c|}{$\begin{array}{l}\text { 1.Lokasi } \\
\text { Universitas } \\
\text { Widyatama yg } \\
\text { berada dekat } \\
\text { pusat kota }\end{array}$} & \multicolumn{2}{|c|}{$\begin{array}{l}\text { 2.Tersedia-nya } \\
\text { tempat belajar } \\
\text { mengajar yg } \\
\text { tenang dan } \\
\text { nyaman }\end{array}$} & \multicolumn{2}{|c|}{$\begin{array}{l}\text { 3.Dekat dengan } \\
\text { rumah kos/ } \\
\text { tempat tinggal } \\
\text { siswa }\end{array}$} & \multicolumn{2}{|c|}{$\begin{array}{l}\text { 4.Dekat dengan } \\
\text { sarana kebutuhan } \\
\text { mahasiswa } \\
\text { (warnet, wartel, } \\
\text { warung nasi, dll) }\end{array}$} \\
\hline & Freq & $\%$ & Freq & $\%$ & Freq & $\%$ & Freq & $\%$ \\
\hline Sangat Penting & 100 & 62,5 & 100 & 62,5 & 96 & 60 & 49 & 61,25 \\
\hline Penting & 44 & 27,5 & 44 & 27,5 & 46 & 28,75 & 24 & 30 \\
\hline Normal & 16 & 10 & 16 & 10 & 18 & 11,25 & 7 & 8,75 \\
\hline Tidak Penting & 0 & 0 & 0 & 0 & 0 & 0 & 0 & 0 \\
\hline \multirow[t]{2}{*}{ Sgt tdk penting } & 0 & 0 & 0 & 0 & 0 & 0 & 0 & 0 \\
\hline & 160 & 100 & 160 & 100 & 160 & 100 & 160 & 100 \\
\hline
\end{tabular}


Untuk tempat (place), hasil penelitian menunjukkan bahwa :

a. Tersedianya tempat belajar mengajar yang tenang \& nyaman merupakan pilihan utama siswa SMU / Sederajat dengan 57,5\% pemilih.

b. Lokasi yang dekat dengan pusat kota, dekat dengan sarana kebutuhan mahasiswa seperti warnet, wartel, warung nasi dan dekat tempat kos mahasiswa merupakan pilihan kedua, ketiga dan keempat dengan perolehan $45 \%, 40,62 \%$ dan $22,5 \%$ pemilih.

5. Orang yang berhubungan langsung dengan kegiatan kemahasiswaan di Universitas Widyatama (People)

\begin{tabular}{ccccccc}
\hline Tanggapan & $\begin{array}{l}\text { 1. Adanya staf pengajar } \\
\text { yg berkualiatas \& } \\
\text { Responden } \\
\text { mengajikar di PTN \& }\end{array}$ & $\begin{array}{l}\text { 2. Kemampuan staff } \\
\text { pengajar dalam } \\
\text { melakukan } \\
\text { PTS terkemuka }\end{array}$ & $\begin{array}{l}\text { Coaching \& } \\
\text { Counseling }\end{array}$ & \multicolumn{1}{l}{$\begin{array}{l}\text { 3. Bobot materi } \\
\text { yang diberikan } \\
\text { oleh staff } \\
\text { pengajar }\end{array}$} \\
& Freq & $\mathbf{9}$ & Freq & \% & Freq & \% \\
\hline Sangat Penting & 36 & 22,5 & 100 & 62,5 & 118 & 73,75 \\
\hline Penting & 90 & 56,25 & 44 & 27,5 & 26 & 16,25 \\
\hline Normal & 34 & 21,25 & 16 & 10,0 & 16 & 10,0 \\
\hline Tidak Penting & 0 & 0 & 0 & 0 & 0 & 0 \\
\hline Sgt tdk penting & 0 & 0 & 0 & 0 & 0 & 0 \\
\hline & $\mathbf{1 6 0}$ & $\mathbf{1 0 0}$ & $\mathbf{1 6 0}$ & $\mathbf{1 0 0}$ & $\mathbf{1 6 0}$ & $\mathbf{1 0 0}$ \\
\hline
\end{tabular}

Untuk People, hasil penelitian menunjukkan bahwa :

a. Bobot materi yang diberikan oleh staf pengajar merupakan pilihan utama siswa lulusan SMU / Sederajat dengan $73,75 \%$ pemilih.

b. Kemampuan staf pengajar dalam melakukan coaching \& counseling dan adanya staff pengajar yang berkualitas \& memiliki pengalaman mengajar di PTN-PTS merupakan pilihan kedua dan ketiga responden.

6. Proses kegiatan kemanusiaan di Universitas Widyatama (Process)

\begin{tabular}{|c|c|c|c|c|c|c|c|c|c|c|}
\hline \multirow[t]{2}{*}{$\begin{array}{l}\text { Tanggapan } \\
\text { Responden }\end{array}$} & \multicolumn{2}{|c|}{$\begin{array}{l}\text { 1. Pelayanan } \\
\text { terhadap } \\
\text { mahasiswa }\end{array}$} & \multicolumn{2}{|c|}{$\begin{array}{l}\text { 2. Kedata-ngan } \\
\text { Staf } \\
\text { Pengajar }\end{array}$} & \multicolumn{2}{|c|}{$\begin{array}{l}\text { 3. Komunikasi } \\
\text { dengan staff } \\
\text { pengajar }\end{array}$} & \multicolumn{2}{|c|}{$\begin{array}{l}\text { 4. Bobot Diktat } \\
\text { kuliah yang } \\
\text { diberikan }\end{array}$} & \multicolumn{2}{|c|}{$\begin{array}{l}\text { 5. Kecepatan } \\
\text { pengumuman } \\
\text { hasil ujian yg } \\
\text { telah } \\
\text { diselenggarakan }\end{array}$} \\
\hline & Freq & $\%$ & Freq & $\%$ & Freq & $\%$ & Freq & $\%$ & Freq & $\%$ \\
\hline Sangat Penting & 90 & 56,2 & 78 & 48,8 & 46 & 28,8 & 36 & 22,5 & 118 & 73,8 \\
\hline Penting & 46 & 28,8 & 44 & 27,5 & 66 & 41,2 & 50 & 31,25 & 26 & 16,3 \\
\hline Normal & 24 & 15 & 22 & 13,7 & 48 & 30 & 54 & 33,75 & 16 & 8 \\
\hline Tidak Penting & 0 & 0 & 16 & 10 & 0 & 0 & 16 & 10 & 0 & 0 \\
\hline Sgt tdk penting & 0 & 0 & 0 & 0 & 0 & 0 & 4 & 2,5 & 0 & 0 \\
\hline & 160 & 100 & 160 & 100 & 160 & 100 & 160 & 100 & 160 & 100 \\
\hline
\end{tabular}

Untuk Process, hasil penelitian menunjukkan bahwa :

a. Bobot Diktat kuliah yang diberikan merupakan pilihan utama para mahasiswa dengan $72,5 \%$ pemilih, dan pilihan kedua adalah kedatangan staff pengajar $65 \%$ pemilih.

b. Pilihan ketiga, keempat dan kelima adalah kecepatan hasil pengumuman ujian (37,5\%), pelayana terhadap mahasiswa (35\%) dan faktro komunikasi dengan staff pengajar $(31,25 \%)$. 
Analisis Faktor-Faktor (7P) Yang Mempengaruhi Minat Lulusan SMU / Sederajat Melanjutkan Studinya di Universitas Widyatama

7. Fasilitas Fisik yang disediakan oleh Universitas Widyatama (Phisycal Evidence)

\begin{tabular}{|c|c|c|c|c|c|c|c|c|c|c|}
\hline \multirow[t]{2}{*}{$\begin{array}{l}\text { Tanggapan } \\
\text { Responden }\end{array}$} & \multicolumn{2}{|c|}{$\begin{array}{l}\text { 1. Adanya Tempat } \\
\text { kuliah yang } \\
\text { besar, luas } \\
\text { serta fasilitas } \\
\text { parkir yang } \\
\text { luas }\end{array}$} & \multicolumn{2}{|c|}{$\begin{array}{l}\text { 2. Sarana } \\
\text { olahraga yang } \\
\text { tersedia }\end{array}$} & \multicolumn{2}{|c|}{$\begin{array}{l}\text { 3. Sarana } \\
\text { Ibadah } \\
\text { yang } \\
\text { tersedia }\end{array}$} & \multicolumn{2}{|c|}{$\begin{array}{l}\text { 4. Sarana } \\
\text { Poliklinik \& } \\
\text { Kantin } \\
\text { Mahasiswa }\end{array}$} & \multicolumn{2}{|c|}{$\begin{array}{l}\text { 5. Sarana } \\
\text { penunjang } \\
\text { kebutuhan } \\
\text { mahasiswa } \\
\text { (Bank, ATM } \\
\text { dan tempat } \\
\text { photo copy) } \\
\end{array}$} \\
\hline & Freq & $\%$ & Freq & $\%$ & Freq & $\%$ & Freq & $\%$ & Freq & $\%$ \\
\hline Sangat Penting & 80 & 50,0 & 42 & 26,25 & 76 & 47,5 & 72 & 45 & 82 & 51,25 \\
\hline Penting & 62 & 38,75 & 76 & 47,5 & 68 & 42,5 & 70 & 43,75 & 65 & 40,63 \\
\hline Normal & 8 & 5 & 26 & 16,25 & 16 & 10 & 18 & 11,25 & 13 & 8,12 \\
\hline Tidak Penting & 10 & 6,25 & 16 & 10 & 0 & 0 & 0 & 0 & 0 & 0 \\
\hline Sgt tdk penting & 0 & 0 & 0 & 0 & 0 & 0 & 0 & 0 & 0 & 0 \\
\hline & 160 & 100 & 160 & 100 & 160 & 100 & 160 & 100 & 160 & 100 \\
\hline
\end{tabular}

Untuk Fasilitas Fisik (Phisycal Evidence), hasil peneli /tian menunjukkan bahwa :

a. Tersedianya sarana penunjang (Bank, ATM dan tempat photo copy) bagi mahasiswa merupakan pilihan utama dengan $51,25 \%$ pemilih, pilihan kedua ialah tempat kuliah yg besar serta sarana parkir yang luas dengan $50 \%$ pemilih.

b. Pilihan ketiga, keempat dan kelima adalah sarana ibadah (47,5\%), poliklinik \& kantin mahasiswa $(45 \%)$ serta sarana olahraga $(26,75 \%)$

\subsection{Kesimpulan}

\section{KESIMPULAN DAN SARAN}

1. Dari Hasil analisis ditentukan bahwa Product (X1), Price (X2), Promotion (X3) dan Place (X4) merupakan faktor yang signifikan terhadap keinginan responden, sedangkan faktor Person (X5), Process (X6) dan Phisycal Evidence (X7) tidak signifikan terhadap keinginan responden.

2. Beberapa alasan bahwa faktor-faktor Person (X5), Process (X6) dan Phisycal Evidence (X7) dinyatakan tidak signifikan adalah sebagai berikut:

a. Para siswa lulusan SMU / Sederajat yang mendaftarkan diri sebagai calon mahasiswa ratarata tidak mengenal staf pengajar yang akan mengajarkan mereka nanti.

b. Para siswa lulusan SMU/Sederajat yang mendaftarkan diri belum mengetahui proses belajar mengajar di Universitas Widyatama.

c. Tidak semua siswa lulusan SMU/Sderajat tertarik dengan fasilitas yang disediakan oleh Universitas Widyatama, seperti fasilitas olahraga dan fasilitas perpakiran. Hal ini dapat dilihat dari tanggapan responden, dimana $26,25 \%$ diantaranya beranggapan bahwa hal ini tidak penting.

3. Hasil pembahasan menunjukkan bahwa pengaruh faktor-faktor yang signifikan seperti Product (X1), Price (X2), Promotion (X3), dan Place (X4) terhadap minat adalah $24,45 \%$. Oleh sebab itu masih ada faktor-faktor lain yang dapat mempengaruhi minat lulusan SMU/Sederajat, dimana sesuai hasil penelitian Promosi menunjukkan yang tertinggi, yaitu sebesar $40 \%$ atau 0,4 .

4. Hasil wawancara dengan bagian marketing Universitas Widyatama menunjukkan bahwa untuk tingkat nasional nama dan identitas Universitas Widyatama belum dikenal luas, hal ini menjadi tantangan mereka untuk dapat memperkenalkan nama Universitas Widyatama secara lebih luas dan sesuai dengan hasil pembahasan dimana faktor produksi merupakan salah satu faktor yang harus lebih ditingkatkan lagi. 


\subsection{Saran-saran}

Setelah melakukan aktivitas penelitian dan mengambil kesimpulan dari peneitian yang penulis lakukan, ada beberapa hal yang ingin penulis sampaikan, yaitu sebagai berikut:

1. Untuk lebih memperkenalkan nama dan kualitas Universitas Widyatama, perlu untuk lebih ditonjolkan nama besar para staf pengajar yang telah memiliki pengalaman dan citra yang baik di masyarakat dengan memperbanyak promosi dan iklan-iklan melalui poster-poster, radio, televisi maupun melalui internet.

2. Informasi mengenai proses belajar mengajar di Universitas Widyatama hendaknya dapat dikenal oleh para calon mahasiswa atau lulusan SMU/Sederajat, caranya ialah dengan memasukan semua data yang berhubungan dengan kebutuhan mahasiswa, mulai dari cara pendaftaran, jurusan yang tersedia, mata kuliah, nama staf pengajar serta kemudahan dalam melakukan coaching \& counseling yang semuanya dapat dilihat di Web Universitas Widyatama, dimana para calon mahasiswa dapat mengakses langsung melalui internet.

3. Perlu dilakukan Promosi terhadap fasilitas fisik yang berhubungan dengan pengembangan Universitas Widyatama dan adanya jurusan-jurusan baru yang dibuka sesuai dengan kebutuhan saat ini, hal ini juga merupakan salah satu cara bagi Universitas Widyatama untuk menarik minat siswa lulusan SMU/Sederajat.

\section{DAFTAR PUSTAKA}

[1] Chaplin JP, Dictionary of Psychology, Dell Publishing Co, New York, 1979

[2] Kotler Philip, Keller Kevin Lane, Manajemen Pemasaran, Edisi Bahasa Indonesia, Cetakan II, PT Indeks, 2007

[3] Djaslim Saladin, Manajemen Pemasaran Edisi kedua, Penerbit CV Linda Karya. 2003.

[4] Stanton, William J, Prinsip Pemasaran jilid I, edisi ke 7, Erlangga Jakarta, 1993

[5] Kotler, Philip, Marketing Management : Analysis, Planning, Implementation and Control . Tenth Edition, New Jersey, Prentice Hall Inc, 2000.

[6] Kotler, Philip, Manajemen Pemasaran, buku satu, edisi Indonesia, Penerbit Salem Empat, 1995

[7] Yazid, Pemasaran Jasa Konsep dan Implementasi, edisi kedua 2001.

[8] Porter Michael E, Competitive Strategy Techniques for Analyzing Industries and Competitors New York, 1980

[9] Anderson Rolph E, Joseph F Hair JR, Ronald L Tatham, Multivariate Data Analysis, Collier Macmillan Canada Inc, 1990. 